\title{
The Effect Of Auditor Designation On Audit Opinion: Evidence From Korea
}

Haeyoung Ryu, Yonsei University, South Korea

\begin{abstract}
Korea introduced the auditor designation system as an exception to the free audit engagement system in 1991. The auditor designation system is a system in which Securities \& Futures Commission designates an auditor for companies that are highly likely to manipulate their accounting information so as to conduct fair auditing.

The meaning of this study is in that it focused on the auditor designation system, which is only enforced in Korea around the world, to investigate whether auditors of companies designated with an auditor express conservative opinions in comparison to companies without designation. This study also examined whether designated auditors give more conservative opinions to companies showing low quality of financial reporting.

As a result of verification, companies designated with an auditor were found to have greater possibility of receiving adverse audit opinions compared to companies without designation, and lower quality of financial statements resulted in adverse audit opinions. Such results indicate that designated auditors perform stricter and more independent auditing. The results of this study can provide useful implications to other nations attempting to introduce the auditor designation system.
\end{abstract}

Keywords: Auditor Designation; Audit Opinion

\section{INTRODUCTION}

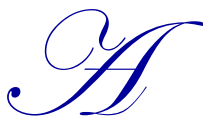

$\mathrm{s}$ a product of social institution, accounting audit has undergone many changes as various institutional devices were enforced and supplemented to improve audit quality. Korea brought force an innovation in the method of auditor selection in 1982. The auditor assignment system enforced until 1981 was transformed into the free audit engagement system. The free audit engagement system gained persuasive power because of its advantage to reinforce expertise and competitiveness of auditors by efficiently distributing audit resources based on the market principles. However, the free audit engagement system was revealed to have a problem in securing independence of auditors. As a means to supplement this problem, Korea introduced the auditor designation system starting in January 1990.

The auditor designation system is a system in which Securities \& Futures Commission designates an auditor for companies that correspond to certain criteria regulated in 'the Act on External Audit of Stock Companies' for the purpose of accomplishing policy goal of protecting investors and creditors by providing reliable accounting information. Most of companies designated with an auditor are under surveillance sanction, have administrative issues, or are waiting for new listing. Companies designated with an auditor are characterized by violation of accounting standards, audit opinions that are adverse, and extremely low level of exposure of accounting information to the capital market. In addition, these companies have high uncertainty in persistence as going concerns, high risk of business failure, and high information risk with agent problem caused by information asymmetry.

As such, since companies designated with an auditor fail to give trust to participants of the capital market about reliability of their accounting information, participants of the capital market will respond very sensitively to 
reliability of accounting information. Furthermore, it can be inferred that designated auditors would avoid audit risks and act more conservatively about future uncertainties based on their reinforced independence. Although managers and auditors sequentially participate in public announcement of accounting information, designated auditors will conduct audit more carefully and strictly compared to other auditors in order to increase reliability of financial statements, considering that financial statements are restated or audit opinions are formed based on mutual exchange of opinions in the auditing process. Due to such tendencies of designated auditors, they are probably more likely to express conservative audit opinions about companies being audited. Therefore, this study aims to verify whether companies designated with an auditor have greater possibility of receiving adverse audit opinions compared to companies without designation. Its additional contribution is in verification of whether designated auditors are more likely to express adverse audit opinions when quality of financial statements of is low, and whether reliability of accounting information pursued by the auditor designation system is achieved from the perspective of audit opinions.

This study consists of the following. Chapter II introduces theoretical background, summarizes previous studies and sets forth the hypothesis of this study. Chapter III explains the process of selecting samples used for testing of the hypothesis and study model. Chapter IV explains the results of empirical analysis, and Chapter V summarizes the conclusions and contributions of this study.

\section{THEORETICAL BACKGROUND, LITERATURE REVIEW AND HYPOTHESES}

\section{Theoretical Background and Literature Review}

Korea has been adopting the assignment system in which the government forcibly assigned an auditor to companies subject to audit until 1981, but it was changed to the free audit engagement system allowing companies subject to audit to freely select their own auditor in 1982 with the enactment of 'the Act on External Audit of Stock Companies' in 1981. Whereas the free audit engagement system has an advantage of inducing systematization and enlargement of auditors and improving quality of audit service, there have been arguments that over-competition of auditors deduces independence of auditors and causes problem in reliability of financial statements announced by companies. Under such background, the auditor designation system was implemented on January 1, 1990 for the purpose of limiting a portion of auditor appointment right in companies and enhancing independence of auditors shown by the free audit engagement system. Appointment of auditors in Korea is generally done according to the principle of freedom of contract, but an external auditor is designated by Securities \& Futures Commission for specific companies that are recognized to be in need of fair audit for protecting users of accounting information.

This system allows for independent and fair external audit. Su-Yeong Kwon et al. (2004) used discretionary accruals in companies designated with an auditor from 1991 to 2000 to analyze whether auditor retention and auditor rotation of the auditor designation system improves independence of auditors. According to their study result, discretionary accruals were significantly lower for designated years of designated companies than undesignated years or undesignated companies. In addition, discretionary accruals of companies designated because of high audit risk were lower than discretionary accruals of companies designated because of low audit risk. This can be understood as provision of stricter audit quality by designated auditors. Se-Yong Lee et al. (2009) analyzed market response before and after designation of auditor using cumulative abnormal return on 179 companies designated with an auditor among companies listed in the securities market from 1994 to 2002. Also, long-term changes in market response to auditor designation were analyzed. As a result of analysis, CAR was founded have significantly positive $(+)$ effect after the auditor designation date. This result suggests that designated auditors are positively received by market participants. Hyuk Shawn (2011) analyzed the effect of the auditor designation system on real earnings manipulation of companies listed in the securities market from 2001 to 2010. He reported that companies designated with an auditor have significantly lower REM than companies without designation, showing reinforced independence of designated auditors.

\section{Hypothesis Development}

According to DeAngelo (1980), audit quality is defined as the possibility in which an auditor discovers a corruption or error in financial statements or possibility of honestly reporting a corruption or error found. In this 
definition, the former is related to expertise of auditor and the latter is related to independence of auditor. In other words, audit quality can only improve reliability of financial statements when both expertise and independence of an auditor are satisfied. The auditor designation system was enforced with a policy intent to increase audit quality and increase reliability of accounting information by preventing weakening of independence of auditors by the free audit engagement system. Companies designated with an auditor are characterized by potential information risk, serious agency problem caused by information asymmetry, and high future uncertainty. Since designated auditors will generally show much more independent and risk-avoiding tendencies than auditors appointed by free audit engagement, they are likely to express strong opinions during announcement of accounting information. In addition, managers and auditors sequentially participate in preparation and auditing of financial statements in the announcement process of accounting information, but position of auditor takes dominance over position of manager in the auditing process.

Previous studies report that designated auditors can increase audit time and demand audit fee in order to increase audit quality because of high audit risk (Jun-Hwa Noh et al. 2003; In-Tae Hwang and Seon-Min Kang 2006) and show much stronger independence compared to auditors of free audit engagement companies as they secure dominant position in the audit contract (Su-Yeong Kwon et al. 2004; Hyuk Shawn 2011). Also, auditors take more audit time into companies with high litigation risk from business failure, and increased audit time according to litigation risk was found to reinforce conservative accounting on financial statements of companies being audited (DeFond and Subramanyam 1998; Cahan and Zhang 2006). Summarizing the results of previous studies explained above, companies designated with an auditor will have independent and risk-avoiding designated auditors who try to settle agency problem from information asymmetry and reduce audit risk from litigation by actively reflecting future uncertainties of companies on financial statements. Therefore, auditors are expected to apply stricter audit standards and express adverse audit opinions for companies designated with an auditor compared to companies without designation. Decreasing audit quality of companies designated with an auditor will result in stricter audit, which increases the likeliness to express adverse audit opinions. Hypotheses 1 and 2 have been set forth as below for such reasons.

Hypothesis 1: Auditor-designated firms are more likely to receive adverse audit opinions than non-designated firms.

Hypothesis 2: Lower quality of financial reporting by auditor-designated firms is more likely to receive adverse audit opinions.

\section{SELECTION OF SAMPLES AND STUDY METHODOLOGY}

\section{Selection of Samples}

The sample for this research is based on firms all listed on both Korean Stock Exchange(KSE) and Korea Securities Dealers Automated Quotations(KOSDAQ) from 2002 to 2010, and following conditions are applied for sample selection and 13,429 firm-year samples were selected as final samples according to the conditions described above.

Table 1. Compositions of Samples

\begin{tabular}{lc}
\hline \multicolumn{1}{c}{ Sample selection process } & Num. of firms \\
\hline All firm observations from Korea Stock Exchange (KSE) and Korea Securities Dealers Automated & 16,344 \\
Quotations (KOSDAQ) during the period 2002-2010Quotations (KOSDAQ) during the period 2002-2010 & $(1,269)$ \\
(Less) Financial service & $(513)$ \\
(Less) Non-December Firms & $(1,133)$ \\
(Less) Firms with insufficient financial data, audit opinion & 13,429 \\
\hline Final Sample Size Used for H1, H2 & \\
Winsorization on sample of upper and lower 1\% level, based on dependent and independent variables & \\
\hline
\end{tabular}




\section{Research Model}

This study attempts to verify whether auditors of companies designated with an auditor express conservative opinions in comparison to companies without designation.

OPN, a dependent variable in the equation below, is a dummy variable that has a value of 1 when audit opinions are adverse and 0 when they are not. The interest variable of this study is DESIG dummy variable that stands for designation of auditor. $\mathrm{DA}^{1}$ variable was used as quality variable of financial statements in order to verify whether auditing becomes stricter due to quality of financial statements. If $\beta 1$ shows statistically significant positive $(+)$ value, it agrees with the hypothesis of this study that auditors are more likely to express adverse audit opinions for companies designated with an auditor.

As for control variables, a dummy variable for BIG 4 accounting companies was included in the model to control the effect of audit quality on dependent variable. ROA, a variable for return on assets, was included in the model to control the effect of corporate performance on audit opinions. Since high cash flow ratio is likely to result in desirable audit opinions, SALES variable calculated by taking natural log of sales was included in the model to control CFO, cash flow ratio from sales activities, and corporate size. Moreover, ZSCORE variable showing bankruptcy risk of companies was included in the model because high bankruptcy risk is likely to result in inappropriate financial statements. Also, first-time auditors can provide strict audit opinions based on higher audit standards because they apply stricter judgment criteria to corruptions and errors reverted to the former auditors. On the contrary, there is a possibility in which they can express audit opinions based on lower audit standards as they reduce audit quality for running audit. As this is considered to affect audit opinions in one way or another, a dummy variable $\mathrm{CHN}$ that shows change in the auditor compared to previous year to control the effect of first-time auditors on audit opinions. GROWTH, a variable for growth in sales compared to previous term, was included in the model to control the effect of growth on audit opinions. Also, a dummy variable called MARKET that shows listing on KOSDAQ was added as companies that belong to KOSPI and companies of KOSDAQ can show collective differences. Lastly, year dummy and industry dummy were included in the model to control the effects of industry and year.

\footnotetext{
${ }^{1}$ We use performance matched discretionary accruals (Kothari et al. 2005) as a proxy for financial reporting quality. To estimate the performance matched accrual, we use following regression model. TA $A_{t} / A_{t-1}=\beta_{0}+\beta_{1}\left(1 / A_{t-1}\right)+\beta_{2}\left(\Delta\right.$ SALES $\left._{t}-\Delta \mathrm{AR}_{t}\right) / A_{t-1}+\beta_{3} \operatorname{PPE}_{t} / A_{t-1}+\beta_{4} \operatorname{ROA}_{t} / A_{t-1}+\varepsilon_{i t}$ where TA is net income minus cash flow from operating activities, $\mathrm{A}$ is total assets, $\triangle \mathrm{SALES}$ is change in sales, $\triangle \mathrm{AR}$ is change in account receivables, PPE is net property, plant and equipment, ROA is return on asset. The performance matched discretionary accruals is estimated cross-sectionally each year using all firm-year observations in the same industry as a residual form of equation above.
} 


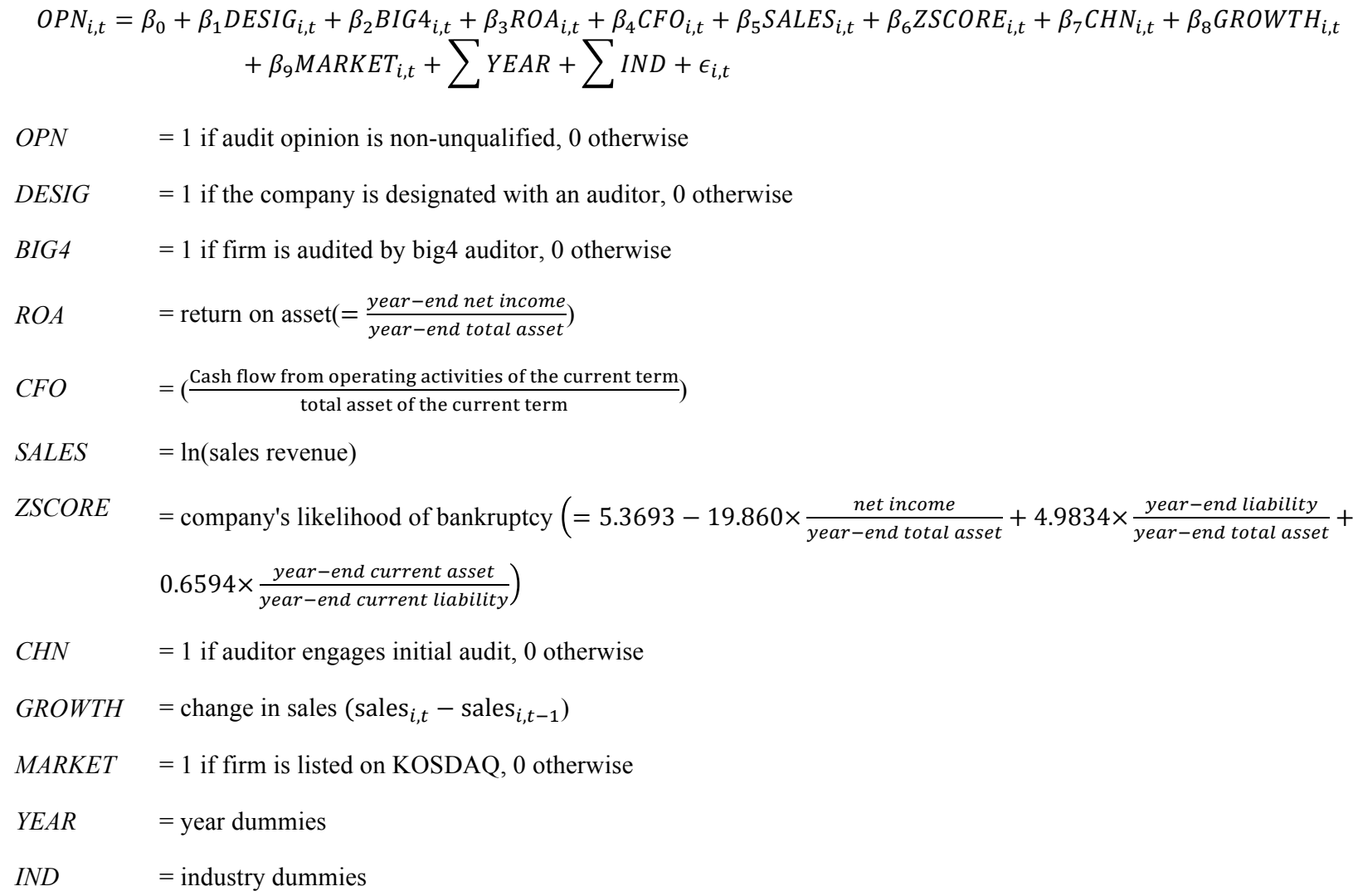

\section{EMPIRICAL RESULTS}

\section{Descriptive Statistics and Correlation Analysis}

Table 2 shows descriptive statistics for the variables. Mean and median value of OPN are 0.006 and 0.00 respectively. Mean and median value of DESIG is 0.036 and 0.00 respectively which implies $3.6 \%$ of firm-year samples were designated to be audited by specific auditor. And the mean(median) value of DA shows $-0.008(0.009)$. $<$ Table 3> shows the correlation among variables used in this study. First, DESIG agreed with the hypothesis by showing a significant positive $(+)$ correlation at $1 \%$ significance level with OPN. As a result of examining the correlation among control variables, correlation between all control variables was less than 0.6 except the correlation between SALES and MARKET. And we found that VIF (Variation Inflation Factor) shows less than 10 implying that there is no multi-colinearity problem. 
Table 2. Descriptive Statistics

\begin{tabular}{lccccc}
\hline Variable & Mean & Standard deviation & Minimum & Median & Maximum \\
\hline OPN & 0.006 & 0.074 & 0 & 0 & 1 \\
DESIG & 0.036 & 0.187 & 0 & 0 & 1 \\
DA & -0.008 & 0.174 & -0.871 & 0.009 & 0.423 \\
BIG4 & 0.143 & 0.35 & -1.684 & 0 & 1 \\
ROA & -0.028 & 0.268 & -0.483 & 0.033 & 0.306 \\
CFO & 0.035 & 0.13 & 16.134 & 23.317 & 0.348 \\
SALES & 22.289 & 2.822 & -7.861 & -2.459 & 26.85 \\
ZSCORE & -0.752 & 6.557 & 0 & 0 & 40.39 \\
CHN & 0.165 & 0.371 & -0.919 & 0.078 & 1 \\
GROWTH & 0.207 & 0.908 & 0 & 1 & 9.001 \\
MARKET & 0.609 & 0.488 & & 1 \\
\hline Varible & & & & \\
\hline
\end{tabular}

Variable definitions:

OPN is 1 if audit opinion is non-unqualified, 0 otherwise,

DESIG is 1 if the company is designated with an auditor, 0 otherwise,

DA is performance matched discretionary accruals,

BIG4 is 1 if firm is audited by big4 auditor, 0 otherwise,

ROA is return on asset(=year-end net income/year-end total asset),

CFO is cash flow from operating activities of the current term divided by total asset of the current term,

SALES is $\ln ($ sales revenue),

ZSCORE is company's likelihood of bankruptcy (=-5.3693-19.860 $\times$ (net income/year-end total asset) $+4.9834 \times($ year-end liability/year-

end total asset $)+0.6594 \times($ year-end current asset/year-end current liability $)$,

$\mathrm{CHN}$ is 1 if auditor engages initial audit, 0 otherwise,

GROWTH is change in sales (=sales for the current period-sales in previous period),

MARKET is 1 if firm is listed on KOSDAQ, 0 otherwise,

Table 3. Pearson's Correlation

\begin{tabular}{|c|c|c|c|c|c|c|c|c|c|c|}
\hline & DESIG & DA & BIG4 & ROA & CFO & SALES & ZSCORE & CHN & GROWTH & MARKET \\
\hline$O P N$ & $\begin{array}{c}0.066 \\
(<.0001) \\
\end{array}$ & $\begin{array}{c}-0.111 \\
(<.0001) \\
\end{array}$ & $\begin{array}{c}-0.023 \\
(0.008) \\
\end{array}$ & $\begin{array}{c}-0.189 \\
(<.0001) \\
\end{array}$ & $\begin{array}{c}-0.111 \\
(<.0001) \\
\end{array}$ & $\begin{array}{c}-0.022 \\
(0.0118) \\
\end{array}$ & $\begin{array}{c}0.180 \\
(<.0001) \\
\end{array}$ & $\begin{array}{c}0.011 \\
(0.1981) \\
\end{array}$ & $\begin{array}{c}-0.008 \\
(0.3832) \\
\end{array}$ & $\begin{array}{c}0.005 \\
(0.5508) \\
\end{array}$ \\
\hline$D E S I$ & & $\begin{array}{c}-0.080 \\
(<.0001)\end{array}$ & $\begin{array}{c}-0.002 \\
(0.8116)\end{array}$ & $\begin{array}{c}-0.163 \\
(<.0001)\end{array}$ & $\begin{array}{c}-0.120 \\
(<.0001)\end{array}$ & $\begin{array}{c}-0.032 \\
(0.0002)\end{array}$ & $\begin{array}{c}0.162 \\
(<.0001)\end{array}$ & $\begin{array}{c}0.200 \\
(<.0001)\end{array}$ & $\begin{array}{c}0.018 \\
(0.041) \\
\end{array}$ & $\begin{array}{c}0.003 \\
(0.719) \\
\end{array}$ \\
\hline$D A$ & & & $\begin{array}{c}0.014 \\
(0.0697) \\
\end{array}$ & $\begin{array}{c}0.695 \\
(<.0001) \\
\end{array}$ & $\begin{array}{c}-0.054 \\
(<.0001) \\
\end{array}$ & $\begin{array}{c}0.058 \\
(<.0001) \\
\end{array}$ & $\begin{array}{c}-0.621 \\
(<.0001)\end{array}$ & $\begin{array}{c}-0.028 \\
(0.0002)\end{array}$ & $\begin{array}{c}0.019 \\
(0.0137) \\
\end{array}$ & $\begin{array}{c}-0.003 \\
(0.6993) \\
\end{array}$ \\
\hline$B I G 4$ & & & & $\begin{array}{c}0.076 \\
(<.0001) \\
\end{array}$ & $\begin{array}{c}0.083 \\
(<.0001) \\
\end{array}$ & $\begin{array}{c}-0.036 \\
(<.0001) \\
\end{array}$ & $\begin{array}{c}-0.069 \\
(<.0001) \\
\end{array}$ & $\begin{array}{c}-0.024 \\
(0.0017) \\
\end{array}$ & $\begin{array}{c}0.001 \\
(0.9021) \\
\end{array}$ & $\begin{array}{c}-0.103 \\
(<.0001) \\
\end{array}$ \\
\hline$R O A$ & & & & & $\begin{array}{c}0.569 \\
(<.0001)\end{array}$ & $\begin{array}{c}0.031 \\
(<.0001)\end{array}$ & $\begin{array}{c}-0.908 \\
(<.0001)\end{array}$ & $\begin{array}{c}-0.017 \\
(0.0227)\end{array}$ & $\begin{array}{c}0.092 \\
(<.0001)\end{array}$ & $\begin{array}{c}-0.129 \\
(<.0001)\end{array}$ \\
\hline$C F O$ & & & & & & $\begin{array}{c}0.084 \\
(<.0001) \\
\end{array}$ & $\begin{array}{c}-0.517 \\
(<.0001) \\
\end{array}$ & $\begin{array}{c}-0.010 \\
(0.1919) \\
\end{array}$ & $\begin{array}{c}0.068 \\
(<.0001) \\
\end{array}$ & $\begin{array}{c}-0.062 \\
(<.0001) \\
\end{array}$ \\
\hline SALES & & & & & & & $\begin{array}{c}-0.033 \\
(<.0001) \\
\end{array}$ & $\begin{array}{c}-0.032 \\
(<.0001) \\
\end{array}$ & $\begin{array}{c}0.089 \\
(<.0001) \\
\end{array}$ & $\begin{array}{c}0.881 \\
(<.0001) \\
\end{array}$ \\
\hline ZSCORE & & & & & & & & $\begin{array}{c}0.012 \\
(0.1121) \\
\end{array}$ & $\begin{array}{c}-0.085 \\
(<.0001) \\
\end{array}$ & $\begin{array}{c}0.143 \\
(<.0001) \\
\end{array}$ \\
\hline$C H N$ & & & & & & & & & $\begin{array}{c}0.009 \\
(0.2371)\end{array}$ & $\begin{array}{c}-0.030 \\
(<.0001)\end{array}$ \\
\hline GROWTH & & & & & & & & & & $\begin{array}{c}0.070 \\
(<.0001)\end{array}$ \\
\hline
\end{tabular}

Variable definitions: refer to Table 2. Values in parentheses are p-values.

\section{Multivariate Logistic Analysis}

Table 4 provides the results of logistic analysis tested out using OPN dummy variable as dependent variable in order to examine the effect of auditor designation on auditor opinion. Key variable is DESIG and if the sign of coefficient $\alpha 1$ is significant positive $(+)$ value, it corresponds to hypothesis 1 . 
As a result of analysis, estimated value of DESIG was 0.7874 (Wald $\chi^{2}=4.1494$ ). It has significantly positive (+) influence on dependent variable at 5\% significance level. This result corresponds to hypothesis 1 of this study that designated auditor audited with caution client firm. Key variable is the interaction variable of UEOI, unexpected operating income rate, and NOE. As a result, the coefficient a1 is negatively significant at $10 \%$ significance. These result imply that firms with frequent shifting activity shows low accuracy on the analysts' earnings forecasts.

Table 4. Empirical Result (Hypothesis 1)

\begin{tabular}{|c|c|c|}
\hline Variables & Estimate & $\begin{array}{c}\text { Wald } \\
\text { Chi-Square }\end{array}$ \\
\hline Intercept & -2.2087 & 0.9436 \\
\hline Desig & 0.7874 & $4.1494 * *$ \\
\hline Big4 & -1.2297 & $6.1583^{* *}$ \\
\hline Roa & -1.0143 & 2.0532 \\
\hline $\mathrm{CFO}$ & -3.1639 & $11.2215^{* * *}$ \\
\hline Sales & -0.086 & 0.6414 \\
\hline Zscore & 0.0443 & 2.4907 \\
\hline Chn & -0.1484 & 0.2191 \\
\hline Growth & 0.0902 & 0.6519 \\
\hline Market & 0.0281 & 0.0018 \\
\hline Year Dummies & \multirow{4}{*}{\multicolumn{2}{|c|}{$\begin{array}{c}\text { Included } \\
\text { Included } \\
13,429 \\
0.308\end{array}$}} \\
\hline Industry Dummies & & \\
\hline Obs & & \\
\hline Pseudo $R^{2}$ & & \\
\hline
\end{tabular}

As a result of analysis, estimated value of DESIG was 0.7874 (Wald $\chi^{2}=4.1494$ ). It has significantly positive $(+)$ influence on dependent variable at $5 \%$ significance level. This result corresponds to hypothesis 1 of this study that designated auditor audited with caution client firm. Key variable is the interaction variable of DA and DESIG. As a result, the coefficient a3 is positively significant at 5\% significance level. This result implies that firms with worse financial reporting quality have a tendency to be audited more carefully by designated auditor.

Table 5 is table that shows verification result for hypothesis 2 , which predicts that designated auditors are more likely to apply stricter audit on companies with low quality of financial report. It suggests the result of logistic analysis performed using audit opinion as a dependent variable. If designated auditors apply stricter audit on companies with lower quality of financial report measured as DA as set forth in the hypothesis of this study, the coefficient of interactive variable of DESIG and DA will return a significant positive $(+)$ value.

Table 5. Empirical Result (Hypothesis 2)

\begin{tabular}{|c|c|c|}
\hline Variables & Estimate & $\begin{array}{c}\text { Wald } \\
\text { Chi-Square } \\
\end{array}$ \\
\hline Intercept & -2.2365 & 0.9711 \\
\hline Desig & 1.2376 & $8.9903 * * *$ \\
\hline$D A$ & -1.5258 & 1.8445 \\
\hline Desig $* D A$ & 1.8185 & $4.2195 * *$ \\
\hline Big4 & -1.2186 & $6.0053 * *$ \\
\hline Roa & -0.1662 & 0.0269 \\
\hline $\mathrm{CFO}$ & -4.1054 & $10.7656^{* * *}$ \\
\hline Sales & -0.0795 & 0.5534 \\
\hline Zscore & 0.0488 & $3.2433^{*}$ \\
\hline Chn & -0.1709 & 0.2969 \\
\hline Growth & 0.0704 & 0.3776 \\
\hline Market & 0.00012 & 0.0001 \\
\hline Year Dummies & & \\
\hline Industry Dummies & & \\
\hline Obs & & \\
\hline Pseudo $R^{2}$ & & \\
\hline
\end{tabular}




\section{The Effect of Types of Enforcement Actions on Audit Opinions (Additional Test)}

Enforcement actions are caused by various reasons such as companies with administrative issues (DESIG1), companies preparing for initial public offering (DESIG2), companies that have not appointed an auditor (DESIG3), companies selected for investment alert issues (DESIG4), and companies that requested enforcement action (DESIG5). As there are such diverse reasons for enforcement actions, this Chapter aims to specifically verify which reasons have negative effect on audit opinions.

The results are as shown in $<$ Table 6>. DESIGR1 for administrative issues and DESIGR4 for investment alert issues were found to have significant positive $(+)$ effect on dependent variable OPN. The estimated value of DESIGR1 was 0.9514 (Wald $\chi^{2}=4.162$ ) implying that $5 \%$ significance level and the estimated value of DESIGR4 was 3.191 (Wald $\chi^{2}=8.5858$ ) implying that $1 \%$ significance level. The results in $<$ Table $6>$ support robustness of the study results as they agree with the basic hypothesis testing results of this study.

Table 6. The Effect of Types of Enforcement Actions on Audit Opinions (Additional Test)

\begin{tabular}{|c|c|c|}
\hline Variables & Estimate & $\begin{array}{c}\text { Wald } \\
\text { Chi-Square } \\
\end{array}$ \\
\hline Intercept & -2.1891 & 0.9124 \\
\hline DESIGR1 & 0.9514 & $4.162 * *$ \\
\hline DESIGR2 & -11.2853 & 0.0001 \\
\hline DESIGR3 & -9.9233 & 0.0001 \\
\hline DESIGR4 & 3.181 & $8.5858 * * *$ \\
\hline DESIGR5 & -11.7437 & 0.0001 \\
\hline$D A$ & -1.0428 & 0.8727 \\
\hline Big4 & -1.2096 & $5.9841 * *$ \\
\hline Roa & -0.3347 & 0.1038 \\
\hline$C F O$ & -3.879 & $9.2009 * * *$ \\
\hline Sales & -0.0834 & 0.5949 \\
\hline Zscore & 0.0451 & 2.6065 \\
\hline Chn & -0.2204 & 0.4594 \\
\hline Growth & 0.0914 & 0.6606 \\
\hline Market & -0.0166 & 0.0006 \\
\hline Year Dummies & & Included \\
\hline Industry Dummies & & Included \\
\hline Obs & & 13,429 \\
\hline Pseudo $R^{2}$ & & 0.319 \\
\hline
\end{tabular}

\section{SUMMARY AND CONCLUSION}

Accounting audit is a social institutional device introduced as a means to settle agency problem and information risk caused by information asymmetry. Accordingly, the purpose of accounting audit is to improve reliability of financial statements for protection of users of accounting information and promotion of sound corporate development. It is important to maintain certain quality of accounting audit in order to play the intended role. The auditor designation system is a system in which an auditor is designated for companies that fall under prescribed criteria to achieve the policy goal of protecting investors and creditors through provision of reliable accounting information. Most of companies designated with an auditor are under surveillance sanction, have administrative issues, or are waiting for new listing. Companies designated with an auditor are characterized by violation of accounting standards, audit opinions that are adverse, and extremely low level of exposure of accounting information to the capital market. In addition, these companies have high uncertainty in persistence as going concerns, high risk of business failure, and high information risk with agent problem caused by information asymmetry. This study attempted to confirm whether reliability of accounting information intended by the auditor designation system is accomplished from the perspective of audit opinions by empirically verifying the effect of auditor designation on audit opinions. 
As a result, companies designated with an auditor were more likely to receive adverse audit opinions compared to companies without designation, and lower quality of financial statements of companies designated with an auditor resulted in adverse audit opinions. Such results indicate that auditors perform stricter and more independent audit on companies designated with an auditor. Moreover, the result of additional test showed that companies designated with an auditor because of administrative issues and investment alert issues showed greater possibility of receiving adverse audit opinions than other companies.

The results of this study offers useful implications to nations that plan to implement the auditor designation system by showing that auditors with increased independence under the auditor designation system perform stricter audit on designated companies, especially with greater possibility of expressing adverse audit opinions on companies with low quality of financial statements.

\section{AUTHOR INFORMATION}

Haeyoung Ryu, Ph.D., Researcher, Business Research Institute, Yonsei University, 134 Shinchon-dong, Seodaemoon-gu, Seoul, Korea. E-mail: hyryu @yonsei.ac.kr

\section{REFERENCES}

Badertscher, B., J. Phillips, M. Pincus, and S. Rego. (2009). Tax implications of earnings management activities: Evidence from restatements. The Accounting Review, 84(1): 63-97.

Cahan, S. F. and W. Zhang. (2006). After Enron: Auditor conservatism and ex-Andersen clients. The Accounting Review, 81(1): 49-82.

DeAngelo, L. E. (1981). Auditor size and audit quality. Journal of Accounting and Economics, 3: 183-199.

DeFond, M. L., and K. R. Subramanyam. (1998). Auditor changes and discretionary accruals. Journal of Accounting an Economics, 25: 35-68.

Hwang, I. T. and S. M. Kang. (2006). Do auditor-assigned firms pay appropriate audit fees? Korean Accounting Journal, 15: 91-122.

Kothari, S. P., A. J. Leone, and C. E. Wasley. (2005). Performance matched discretionary accrual measures. Journal of Accounting and Economics, 39: 163-197.

Kwon, S. Y., J. H. Rho, and G. B. Bae. (2004). The effect of auditor designation on discretionary accruals: Auditor rotation and retention requirements in the Korean audit service market. Korean Accounting Review, 29(4): 191-218.

Lee, S. Y., H. R. Jung, and B. G. Roh. (2009). Market responses to mandatory auditor designation. Korean Accounting Review, 34(1): 207-240.

Rho, J. H., G. S. Bae, and Y. S. Cheon. (2003). The effect of auditor designation on audit fees. Korean Accounting Review, 28(4): 177-202.

Shawn, H. (2011). The effect of the auditor designation on real activity earnings management. The Graduate School of Sungkyunkwan University, Seoul. 


\section{NOTES}

